\title{
Criminal Policy di Masa Pandemi Covid-19
}

\author{
Edi Saputra Hasibuan \\ Direktur Eksekutif Lemkapi dan Dosen Fakultas Hukum Universitas Bhayangkara Jakarta Raya \\ Email: hedihasibuan@yahoo.co.id
}

Article info

Received: Mar 8, $2021 \quad$ Revised: Apr 19, 2021 Accepted: Apr 28, $2021 \quad$ Published: Jun 10, 2021

DOI: https://doi.org/10.31599/krtha.v15i1.531

Keywords : Polri, Policy, Pandemic

Abstract : A large country is born from an intelligent government, especially in solving problems and obstacles that always come their way. Likewise today, the emergence of the Covid-19 virus has become a real attack that is not only felt by one or two regions, but throughout the world. This often makes leaders move quickly and swiftly in taking action. Indonesia, which has also felt the massive impact of this pandemic, has made various efforts, both handling and prevention. The National Police, which is at the forefront of security issues in the country, was immediately deployed to curb and secure every are a that became a red zone for the spread of the Covid-19 virus. The implementation of the PSBB and health protocols in each region is implemented by involving the National Police. This turned out to encourage the National Police to make new and effective breakthroughs or policies in order to maintain the situation and order during this pandemic.

Kata kunci : Polri, Kebijakan, Pandemi

Abstrak : Negara yang besar lahir dari pemerintahan yang cerdas, terutama dalam memecahkan masalah dan rintangan yang selalu datang menghampiri. Begitu juga yang terjadi saat ini, kemunculan virus Covid-19 menjadi serangan nyata yang bukan hanya dirasakan oleh satu atau dua wilayah, namun di seluruh dunia. Hal ini acapkali membuat para pemimpin bergerak cepat dan sigap dalam mengambil tindakan. Indonesia yang juga merasakan dampak masive dari pandemi ini telah melakukan berbagai upaya, baik penanganan maupun pencegahan. Polri yang merupakan garda terdepan soal keamanan dalam negara langsung diterjunkan untuk menertibkan dan mengamankan setiap wilayah yang menjadi zona merah penyebaran virus Covid-19. Penerapan PSBB serta protokol kesehatan di setiap daerah di terapkan dengan melibatkan Polri. Hal ini ternyata mendorong Polri untuk membuat gebrakan atau kebijakan baru yang efektif dalam rangka menjaga situasi dan ketertiban di masa pandemi ini. 


\section{PENDAHULUAN}

Secara universal, tugas pokok lembaga kepolisian mencakup dua hal, yaitu pemeliharaan keamanan dan ketertiban (peace and order maintenance) dan penegakan hukum (law enforcement.$^{1}$

Dalam perkembangannya, tanggung jawab "pemeliharaan" dipandang pasif, sehingga tidak mampu menanggulangi kejahatan. Polisi kemudian dituntut untuk secara proaktif melakukan "pembinaan", sehingga tidak hanya "menjaga" agar keamanan dan ketertiban terpelihara, tetapi juga menumbuhkan kesadaran masyarakat agar taat terhadap hukum, menggugah dan mengajak peran serta masyarakat dalam upaya pemeliharaan keamanan dan ketertiban, dan bahkan ikut memecahkan masalah-masalah sosial yang menjadi sumber kejahatan. Tugas-tugas ini dipersembahkan oleh polisi untuk membantu (to support) masyarakat dalam memenuhi kebutuhannya akan rasa aman, sehingga memungkinkan tercapainya kesejahteraan. ${ }^{2}$

Mekanisme kerja Polri sebagai to support sangat diperlukan terlebih jika dihadapkan dengan situasi global yang dihadapi masyarakat saat ini, dimana sedang mengalami bencana non-alam yaitu Covid-19. Data Pasien positif Covid-19 di Indonesia pada hari Kamis, tanggal 18 Juni 2020 menjadi 42.762 orang. Provinsi Jawa Timur masih menjadi provinsi terbanyak yang menyumbangkan kasus baru hari ini, yaitu 384 kasus dan pasien sembuh 78 .

Posisi kedua ditempati DKI Jakarta dengan tambahan kasus baru sebanyak 173 orang dan sembuh 128 pasien. Sedangkan Sulawesi Selatan menempati urutan ketiga dengan tambahan kasus baru per hari ini sebanyak 166 orang. Provinsi baru yang masuk lima besar adalah Bali dengan penambahan kasus baru sebanyak 66 orang, sementara kasus sembuh bertambah 11 pasien. Berdasarkan data terbaru, pasien Covid-19 yang dilaporkan sembuh hari ini bertambah 555 kasus, sehingga total menjadi 16.798 pasien. Sementara kasus meninggal bertambah 63 orang, total 2.339 kasus. Hingga saat ini, terdapat 23.625 pasien yang sedang menjalani perawatan dan tersebar di 34 provinsi. Sementara itu, Orang Dalam Pemantauan (ODP) sebanyak 36.698, sedangkan Pasien Dalam Pengawasan (PDP) tercatat sebanyak 17.923 orang. $^{3}$

${ }^{1}$ Farouk Muhammad, Menuju Reformasi Polri, cet. Pertama April ,PTIK Press bekerjasama dengan, CV Restu Agung, Jakarta, 2013, hlm. 107.

2 Ibid, Hlm. 108

${ }^{3}$ Sumber: Update Corona Indonesia: Bertambah 1.331 \& Jatim Tertinggi, https://tirto.id/fJyL , diakses ulang pada tanggal 17 Februari 2021, pukul 21.33 Wib 
Menanggapi hal tersebut pemerintah memperketat aturan PSBB dan kewajiban Physical Distancing melalui Peraturan Pemerintah Nomor 21 Tahun 2020 tentang Pembatasan Sosial Berskala Besar (PSBB) dan Peraturan Kementerian Kesehatan (Permenkes) Nomor 9 Tahun 2020.

Menurut Teguh Sudarsono, untuk mewujudkan berbagai tuntutan profesionalisme Polri tidak hanya dilakukan dengan meningkatkan bentuk fisiknya saja seperti penyediaan kantor megah yang disertai peralatan berteknologi menengah dan canggih, atau menata berbagai prosedur kerja untuk membentuk kemampuan personal Polri yang lebih menampakkan sosok penampilan aparat yang profesional, tetapi makna kemandirian dan profesionalisme Polri tersebut hendaknya harus dapat diwujudkan dalam wujud pelaksanaan tugas kepolisian yang mendasarkan pikiran jernih, etika, serta mental dan moral sebagai pengayom, pelindung, dan pelayan masyarakat. ${ }^{4}$

Disamping itu dalam situasi dan kondisi keterbatasan yang dihadapi saat ini dan mendatang harus mau mawas diri dan dapat terus melakukan koordinasi kerja dengan berbagai pihak, agar bermacam tuntutan kebutuhan masyarakat terhadap layanan fungsi kepolisian yang diemban Polri dapat dilakukan secara profesional dan proporsional.

Dalam kehidupan masyarakat global dan modern saat ini, kemandirian Polri tidak sebatas kemandirian institusional (lembaganya), tetapi mandiri dalam berfikir, bersikap dan bertindak. Kemandirian juga harus dilandasi dengan spririt profesionalisme dalam melaksanakan tugasnya sebagai pemelihara keamanan dan ketertiban dalam negeri, sebagai petugas yang harus melayani masyarakat, melindungi dan mengayomi masyarakat serta sebagai petugas penegak hukum.

Dari latar belakang tersebut maka yang menjadi rumusan masalah adalah: (1) Bagaimana peran dan fungsi Polri sebagai salah satu pengaman dan pengayom, khususnya pada masa pandemi virus Covid-19? (2) Apa gagasan serta kebijakan Polri dalam rangka menegakkan aturan pidana maupun aturan terkait Covid-19?

\section{PEMBAHASAN}

\section{A. Polri Pengemban Fungsi Pemerintahan}

Usaha pertahanan dan keamanan Negara dilaksanakan melalui sistem pertahanan dan keamanan rakyat semesta oleh Tentara Nasional Indonesia dan Kepolisian Negara Republik Indonesia, sebagai kekuatan utama, dan rakyat sebagai kekuatan pendukung. ${ }^{5}$

\footnotetext{
4 Teguh Sudarsono, Bianglala, Seganteng Wacana dan Aktualisasi Kelangsungan Reformasi Polri yang Berkelanjutan, Mullia Angkasa, Jakarta, Cetakan Kedua 2015, hlm 3-4

${ }^{5}$ Pasal 30 ayat (2) Undang-Undang Dasar Negara Republik Indonesia Tahun 1945
} 
Berdasarkan ketentuan Pasal 30 ayat (2) di atas, maka Tentara Nasional Indonesia (TNI) dan Kepolisian Negara Republik Indonesia (Polri) merupakan institusi negara yang melaksanakan tugas pemerintahan dalam bidang pertahanan dan keamanan Negara. Di dalam Pasal 30 ayat (4) Undang-Undang Dasar Negara Republik Indonesia Tahun 1945 menentukan, "Kepolisian Negara Republik Indonesia sebagai alat Negara yang menjaga keamanan dan ketertiban masyarakat bertugas melindungi, mengayomi, melayani masyarakat, serta menegakkan hukum"

Keamanan dalam negeri merupakan syarat utama untuk mendukung terwujudnya masyarakat madani yang adil, makmur, dan beradab berdasarkan Pancasila dan Undang-Undang Dasar Negara Republik Indonesia Tahun 1945. Setiap negara hukum memiliki aparat penegak hukum termasuk kepolisian negara yang secara universal mempunyai tugas dan fungsi menjaga keamanan dan ketertiban masyarakat sesuai dengan ketentuan-ketentuan hukum yang berlaku untuk mewujudkan kepastian hukum dan keadilan, fungsi dan tugas Kepolisian Negara Republik Indonesia telah diatur di dalam beberapa ketentuan perundang-undangan. ${ }^{6}$

Fungsi Kepolisian adalah fungsi pemerintahan. Sehingga institusi Kepolisian merupakan lembaga negara yang mempunyai status dan kedudukan sebagai lembaga eksekutif untuk menjalankan fungsi pemerintahan dalam bidang pemeliharaan keamanan dan ketertiban masyarakat, penegakan hukum, perlindungan, pengayoman, dan pelayanan kepada masyarakat. Hal ini sebagaimana ditentukan di dalam Pasal 2 Undang-Undang Nomor 2 Tahun 2002 tentang Kepolisian Negara Republik Indonesia, yaitu "Fungsi kepolisian adalah salah satu fungsi pemerintahan negara di bidang pemeliharaan keamanan dan ketertiban masyarakat, penegakan hukum, perlindungan, pengayoman, dan pelayanan kepada masyarakat.

Keamanan dan ketertiban masyarakat merupakan modalitas pokok dalam mewujudkan cita-cita pembangunan nasional, sehingga usaha untuk menciptakan keamanan dan ketertiban masyarakat harus dilakukan secara sistematis dan komprehensif dalam melaksanakan fungsi Kepolisian tersebut.

Tindakan kepolisian merupakan bagian dari tindak pemerintahan dalam rangka mewujudkan tujuan pemerintahan. Tujuan pemerintahan dimaksud antara lain meliputi: membuat dan mempertahankan hukum atau menjaga ketertiban dan ketentraman (rush and order), merealisasi kehendak negara dan menyelenggarakan

${ }^{6}$ Warsito Hadi Utomo, Hukum Kepolisian di Indonesia, (Jakarta : Presdtasi Pustaka, 2005) Hlm.1 
kepentingan umum (public service). Penyelenggaraan kepentingan umum yang dijalankan pemerintah berupa:

a. Seorang petugas (fungsionaris) atau badan pemerintahan yang berdasarkan peraturan undang-undang diberi kewenganan untuk menyatakan kehendak pemerintah atau penguasa (wil $v / h$ openbaargezag). Dan yang dilengkapi dengan kewenangan (berwenang) melakukan tindakantindakan yang mengikat hukum (persoon of college met enig openbaar gezag bekleed).

b. Badan pemerintahan (openbaar licheam) yaitu kesatuan hukum yang dilengkapi dengan alat-alat atau kewenangan memaksa (de met wereldlijk overheidgezag en phisikle dwangmiddelen toegeruste gemenschappen). ${ }^{7}$

Sebagai alat Negara yang mempunyai fungsi untuk menjaga keamanan dan ketertiban mayarakat, Polri menjadi organisasi yang harus didukung dengan sumbersumber daya yang besar serta profesional. Dukungan SDM ini untuk mewujudkan Polri yang professional dan mandiri. Sehingga dewasa ini yang dibutuhkan oleh polri adalah dukungan sumber daya manusia yang professional. Mengingat sudah banyak fakta yang dapat diketahui dan dirasakan oleh masyarakat mengenai ketidak profesionalannya Polri dalam menjalankan tugas khususnya dalam pelaksanaan penyelidikan dan penyidikan kejahatan.

Tugas esensial Polri adalah memelihara ketertiban dan menjamin keamanan umum serta ketentraman, memberikan pengayoman, perlindungan dan pelayanan kepada masyarakat serta memelihara keselamatan negara dan keselamatan orang, benda serta memberikan perlindungan dan pertolongan. Dengan demikian secara umum tugas Polri adalah menangani masalah-masalah keamanan dalam negeri yang pada intinya adalah menegakkan hukum dalam rangka supremasi hukum.

\section{B. Peran Polri di Masa Pandemi}

Dalam hal menjaga kemanan dan ketertiban yang bermuara pada penegakkan hukum, maka peningkatan koordinasi serta kerja sama yang baik secara proporsional sangat diperlukan, karena masalah keamanan dan penegakkan hukum bukan semata-mata hanya dapat diatasi oleh para aparat penegak hukum/ Polri saja, akan tetapi berbagai aspek serta situasi dan kondisi yang dinamis sangat berpengaruh pada hukum dan keamanan itu sendiri.

7 Kuntjoro Purbopranoto, Beberapa Catatan Hukum Tata Pemerintahan Dan Peradilan Administrasi Negara, (Bandung, Alumni, 1981) Hlm. 41-42 
Upaya preemtif yang dilakukan oleh Pemerintah baik Pemerintah Pusat maupun Pemerintah Daerah yaitu dengan memberikan pemahaman kepada masyarakat untuk meningkatkan kedisiplinan diri agar mengikuti protokol kesehatan. Sedangkan upaya preventif yaitu dengan mengambil kebijakan Pembatasan Sosial Berskala Besar. Upaya pencegahan dan pemutusan rantai penyebaran Covid-19 di Indonesia membutuhkan kedisiplinan pada banyak aspek, terutama kehidupan sosial masyarakat.

Sosok Polri sangat dirasakan dalam kehidupan sehari-hari, terutama dalam masa pandemi ini. Anggota Polri pasti akan menjalin hubungan dengan masyarakat. Hadirnya satgas Covid-19 yang diterjunkan untuk mengawal penerapan protokol kesehatan, dan memastikan penerapan social distancing serta bertindak cepat apabila ada indikasi penyebaran virus, adalah salah satu contoh kongkrit bahwa Polri hadir dan siap untuk masyarakat.

Dalam situasi pandemi, diperlukan disiplin yang sangat ketat terhadap kehidupan sosial masyarakat dalam bentuk physical distancing. Metode ini dianggap sebagai upaya yang paling efektif untuk mencegah dan mengurangi angka penyebaran virus ini. Pemerintah memperkuat kewajiban physical distancing melalui Peraturan Pemerintah Nomor 21 Tahun 2020 tentang Pembatasan Sosial Berskala Besar (PSBB) dan Peraturan Kementerian Kesehatan (Permenkes) Nomor 9 Tahun 2020. Aturan ini harus dipatuhi, dan untuk memastikan kepatuhan tersebut, sosok Polri hadir dan selalu siap menegakkan aturan. Dalam konteks inilah, selain tenaga medis Polri juga menjadi bagian terdepan dalam menangani virus Covid-19.

\section{Kebijakan Penegak Hukum To Support Pada Masa Pandemi Covid-19}

Menyikapi bencana non alam yang terjadi, Pemerintah terus melakukan berbagai upaya untuk melindungi masyarakat. Upaya yang dilakukan oleh Pemerintah Indonesia dalam menanggulangi penyebaran Covid-19, pada garis besarnya mencakup upaya preemtif, preventif dan tindakan represif. Tindakan represif yang dimaksudkan di sini yaitu tindakan restorasi dengan mempersiapkan fasilitas medis untuk menyebuhkan pasien covid-19.

Seperti yang telah dibahas sebelumnya bahwa salah satu upaya dalam menekan angka kematian yang disebabkan oleh virus Covid-19 yaitu dengan Pembatasan Sosial Berskala Besar (PSBB), maka Keberhasilan PSBB memang tergantung dari kesadaran dan kedisiplinan masyarakat, namun untuk memastikan keduanya berjalan, diperlukan peran Polri di dalamnya. Hal ini yang menjadi persoalan. Peran Polri yang demikian krusial dan signifikan untuk mencegah penyebaran Covid-19 tentu menjadi tugas "tambahan" yang 
tidak pernah diduga sebelumnya. Polri, pada satu sisi memiliki tugas-tugas rutin sebagai aparat penegak hukum dan penjaga ketertiban umum, sementara di sisi lain menjadi pihak yang diandalkan untuk menegakkan aturan PSBB. Pada saat yang sama, seluruh personel Polri di lapangan juga harus meningkatkan kewaspadaan bagi dirinya masing-masing karena kemungkinan tertular virus ini juga besar.

Pihak Kepolisian RI menyatakan bahwa penegakan hukum terkait upaya pencegahan penyebaran Covid-19 merupakan pilihan terakhir. Menurut Kepala Bagian Penerangan Umum (Kabagpenum) Divisi Humas Polri KBP. Asep Adi Saputra "Penegakan hukum yang dilakukan Polri selama masa pencegahan penyebaran Covid-19, pada prinsipnya adalah pilihan terakhir atau ultimum remedium,". Upaya yang diutamakan yakni preemtif dan preventif. Menurut Asep, langkah penegakan hukum baru akan dilakukan apabila kedua upaya itu tidak berhasil.

Sejauh ini, Kapolri yang menjabat sebelumnya yaitu Jenderal (Pol) Idham Azis telah mengeluarkan lima surat telegram yang menjadi panduan bagi penyidik di bidang penegakan hukum di tengah wabah Covid-19. Surat telegram ini menjadi panduan bagi jajaran di bawahnya untuk melakukan penegakkan hukum, yaitu:

1. Surat Telegram pertama bernomor ST/1098/IV/HUK.7.1./2020 tentang penanganan kejahatan yang potensial terjadi selama Pembatasan Sosial Berskala Besar (PSBB).

2. Surat Telegram dengan nomor ST/1099/IV/HUK.7.1./2020 tentang penanganan kejahatan dalam ketersediaan bahan pokok.

3. Surat Telegram bernomor ST/1100/IV/HUK.7.1./2020 tentang penanganan kejahatan terkait situasi dan opini di ruang siber.

4. Surat Telegram bernomor ST/1101/IV/HUK.7.1./2020 tentang penanganan kejahatan yang potensial terjadi dalam masa penerapan PSBB. Kelima, telegram bernomor ST/1102/IV/HUK.7.1./2020 tentang penanganan penumpang yang baru tiba atau TKI dari negara endemis atau negara terjangkit Covid-19.

5. Surat Telegram dengan nomor ST/183/II/Ops.2./2021 yang memerintahkan Opspus Aman Nusa II-2021 dan Opsda Aman Nusa II 2021 melakukan sejumlah langkah untuk memperkuat penanganan pandemi Covid-19. Surat Telegram ini adalah yang terbaru dari Polri dalam masa jabatan Kapolri Listyo Sigit.

Ada dua surat telegram yang penulis soroti disini. Yaitu dalam Surat Telegram Nomor : ST/1100/IV/HUK.7.1./2020 pada intinya menekankan kepada Satfung Reskrim terkait perkembangan situasi serta opini di ruang siber dan penegakan hukum 
tindak pidana siber adalah :

1. Melaksanakan koordinasi dengan penyedia jasa internet di wilayah masing-masing;

2. Membantu memberikan akses kepada penyedia jasa internet yang akan melakukan perawatan rutin dan insidental;

3. Berikan dukungan kepada fungsi Humas untuk mensosialisasikan kepada masyarakat terkait dengan kebijakan pemerintah pusat dalam penanggulangan Covid19.

Secara garis besar, sejumlah tindak pidana yang dibidik polisi dalam telegram tersebut antara lain, mereka yang melawan petugas, penimbun bahan pokok, hingga penghina Presiden Joko Widodo maupun pejabat pemerintah lainnya dalam menangani Covid-19 di media sosial. ${ }^{8}$ Lalu selanjutnya adalah surat telegram terbaru dari Kapolri Listyo Sigit. Yaitu surat telegram dengan nomor ST/183/II/Ops.2./2021 yang mana point-pointnya bila dijabarkan seperti berikut: ${ }^{9}$

1. Melakukan Analisis dan evaluasi penanganan Covid-19 bersama Forkompinda, Khususnya terkait dengan efektifitas pelaksanaan PPKM yang telah dilakukan dalam rangka menjaga kesehatan dan keselamatan masyarakat.

2. Komunikasi, kerja sama, dan kolaborasi dengan pemerintah daerah, TNI, pihak rumah sakit, dan stakeholder lainnya untuk menambah kapasitas ryang perawatan dan isolasi pasien Covid-19, serta memprioritaskan perawatan di rumah sakit khusus untuk pasien kritis.

3. Melakukan edukasi dan sosialisasi secara masif agar masyarakat disiplin protocol kesehatan terutama 5M (memakai masker, mencuci tangan, menjaga jarak, menghindari kerumunan, mengurangi mobilisasi).

4. Melakukan pembinaan untuk membangun kampung tangguh nusantara di wilayah masing-masing, sehingga dapat berkontribusi secara nyata dalam rangka mencegah penyebaran dan memberikan perlindungan kepada masyarakat.

5. Melakukan kerja sama dengan pemerintah daerah (satpol PP), TNI, dan stakeholder lainnya.

6. Pelajari, pedomani, dan implementasikan di lapangan semua surat telegram Kapolri terkait penanganan Covid-19 dan penerapannya disesuaikan kondisi di masing-masing wilayah.

\footnotetext{
Pemidanaan dalam Pencegahan Covid-19 Upaya Terakhir https://nasional.kompas.com/read/2020/04/07/06291501/polri-pemidanaan-dalam-pencegahancovid19-upaya-terakhir diakses ulang pada tanggal 18 Februari 2021, Pukul 12:30 Wib

9 Diakses dari https://amp.kompas.com/nasional/read2021/02/02/12371171/ini-6-perintahterbaru-kapolri-soal-penanganan-covid-19 , pada tanggal 18 Februari 2021, pukul 13.45
} 
Surat telegram ini adalah salah satu langkah yang diambil setelah melihat kondisi keamanan dan tingkat penularan yang masih mengalami kenaikan, namun tetap berpedoman juga pada surat telegram yang sebelumnya. Terkait dengan penanganan dan kebijakan dalam menangani tindak pidana di masa pandemi. Beberapa waktu lalu kasus hoax kembali terjadi, kali ini pelaku mengedit berita dengan judul "Corona mewabah, Gubernur Ganjar liburkan sales dan karyawan se-Jateng 2 minggu” padahal berita tersebut tidak benar. Gubernur Jateng justru meliburkan sekolah, yang mana maksudnya agar anakanak tidak tersebar virus Covid-19. Bukan meliburkan karyawan dan para pekerja yang mencari nafkah, karena itu adalah hak mereka. ${ }^{10}$

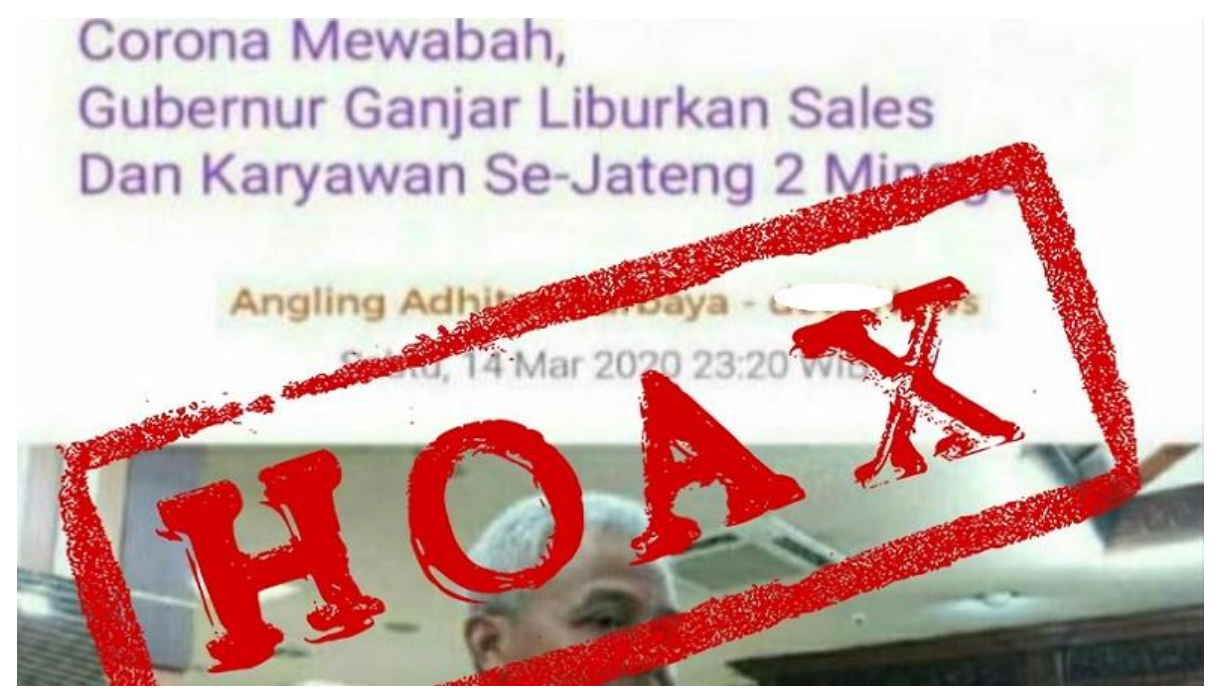

Terhadap kasus di atas, mendapat perhatian khusus Ditreskrimsus Polda Jateng. Sejauh ini ditemukan beberapa informasi hoaks dalam patroli siber yang dilakukan sejak merebaknya pandemi Virus Corona. Kasubdit V Siber Ditreskrimsus Polda Jateng, AKBP Agung Prabowo mengungkapkan, sebagian besar beredarnya informasi hoaks soal Corona itu bermula dari pesan berantai Whatsapp dan sejenisnya. Manurut Agung, Penyidik hanya mengambil langkah persuasif saja. Sebab, kita tidak mau mengambil tindakan yang dapat membuat suasana jadi tidak stabil di tengah isu Corona. ${ }^{11}$

Sebenarnya, penyebar informasi hoax dapat dikenai ancaman hukuman. Biasanya, kata Agung, penyebar hoaks akan diancam hukuman penjara di bawah lima tahun. Namun, Agung mengaku, para penyidik siber biasanya menimbang terlebih dahulu konten informasi hoax yang disebar.

10 Diakses dari: https://news.detik.com/berita-jawa-tengah/d-4939462/corona-mewabahgubernur-ganjar-liburkan-sekolah-se-jateng pada tanggal 20 Februari 2021, Pukul 14.21 Wib

${ }^{11}$ Diakses dari Tribunbanyumas.com dengan judul Polda Jateng: Hoax soal Corona didominasi pesan berantai dari WhatsApp, diakses pada tanggal 20 Februari, Pukul 15.20 Wib 
Jika informasi hoaks yang disebar dapat membuat kegaduhan publik dan menyudutkan, pihakya akan mengambil tindakan. "Tergantung kontennya. Berbau seperti apa. Kan itu macam-macam, bisa sara, fitnah, atau semacamnya. Itu ada di undangundang. Sejauh ini, kalau untuk menangkap penyebar hoax, kita belum sampai ke sana. Namun, temuan hoax Corona di berbagai daerah memang banyak. Yang terpenting, kita tetap stand by patroli siber," Kemudian, Agung juga mengungkapkan, penerus informasi hoax juga dapat terjerat pidana sesuai Pasal 45A ayat (1) Undang-Undang Nomor 19 Tahun 2016. Namun, penyidik biasanya bakal menimbang lebih lanjut fakta hukum keterlibatan seseorang dalam meneruskan informasi hoax. "Sebenarnya penurus informasi ini kan membuat orang lain dapat mengakses informasi hoax itu. Jadi, bisa saja terjerat, namun kita harus cek dulu keterlibatannya seperti apa. Penerus info hoax ini biasanya karena panik. Jika ragu atas info yang didapat, lebih baik didiamkan saja. Tak usah disebar".

Polri tetap menjaga stabilitas keamanan dan kenyamanan dalam masyarakat. Meredam isu hoax yang terus bermunculan sembari menjaga dan memastikan terjaganya protokol kesehatan bersama dengan petugas medis tentu tidaklah mudah. Namun ini sudah menjadi bagian dari peran dan fungsi Polri.

\section{Ketentuan Surat Telegram Kepala Kepolisian Republik Indonesia Nomor : ST/1100/IV/HUK.7.1/2020}

Salah satu strategi atau maupun kebijkan yang dikeluarkan oleh Polri dalam rangka menekan tindak kejahatan baru dan menjaga stabilitas di masa pandemi adalah dengan mengeluarkan surat telegram nomor : ST/1100/IV/HUK.7.1/2020 tentang Pedoman Pelaksanaan Tugas Selama Masa Pencegahan Penyebaran Corona Virus Disease 2019 Covid19 Dalam Pelaksanaan Tugas Fungsi Reskrim Terkait Perkembangan Situasi Serta Opini Di Ruang Siber Dan Penegakan Hukum Tindak Pidana Siber.

Surat Telegram tersebut, ditantangani langsung oleh Kabareskrim Komjen Listyo Sigit Prabowo. Beberapa hal yang termasuk dalam kategori pelanggaran pada masa pandemi Covid-19 yang ditentukan dalam ST/1100/IV/HUK.7.1/2020 adalah :

1. Ketahanan akses data internet selasa masa darurat;

2. Penyebaran hoax terkait Covid-19 dan kebijakan pemerintah dalam mengantisipasi penyebaran wabah Covid-19 sebagaimana dimaksud dalam Pasal 14 dan atau Pasal 15 Undang-Undang Nomor 1 Tahun 1946 Tentang Peraturan Hukum Pidana; 
3. Penghinaan kepada penguasa (Presiden dan Pejabat Pemerintahan) sebagaimana dimaksud Pasal 207 KUHP;

4. Praktek penipuan penjualan online alat-alat kesehatan, masker, alat perlindungan diri, antiseptik, obat-obatan dan disinfektan sebagaimana dimaksud Pasal 45 A ayat (1) Jo Pasal 28 ayat (1) Undang-Undang ITE;

5. Kejahatan orang yang tidak mematuhi penyelenggaraan karantina kesehatan dan atau menghalangi sebagaimana dimaksud Undang-Undang Nomor 6 Tahun 2018 tentang Kekarantinaan Kesehatan Pasal 93.

Dalam ST Nomor : ST/1100/IV/HUK.7.1/2020, langkah-langkah yang dapat diambil oleh Fungsi Reskrim untuk menanggulangi bentuk pelanggaran di atas adalah :

1. Melakukan koordinasi dengan penyedia jasa internet di wilayah masing-masing;

2. Membantu memberikan akses kepada penyedia jasa internet yang akan melakukan perawatan rutin dan insendentil;

3. Berikan dukungan kepada fungsi Humas untuk mensosialisasikan kepada masyarakat terkait dengan kebijakan pemerintah pusat dalam menanggulangi Covid19;

4. Melaksanakan kegiatan kampanye perang terhadap cyber crime;

5. Melaksanakan patroli siber untuk monitoring perkembangan situasi serta opini di ruang siber, dengan sasaran penyebaran hoax terkait Covid-19, hoax terkait kebijakan pemerintah dalam mengantisipasi penyebaran wabah Covid-19, penghinaan kepada penguasa (Presiden) dan Pejabat Pemerintah, praktek penipuan penjualan online, alat-alat kesehatan, masker, alat perlindungan diri, antiseptik, obat-obatan dan disinfektan secara online;

6. Melaksanakan penegakan hukum secara tegas;

7. Ekspose setiap hasil ungkap guna memberi efek jera terhadap pelaku lainnya.

Berdasarkan ketentuan di atas, maka setidaknya ada tujuh poin langkah-langkah yang diperintahkan Kapolri terhadap Kabareskrim Polri dan Kapolda dalam surat telegram tersebut. Dalam pelaksanaannya, surat telegram yang dikeluarkan oleh pihak kepolisian ini didasari dengan aturan lain yaitu KUHP yaitu antara lain :

1. Pasal 156 dan 156a KUHP yang mana ketentuan pada pasal ini dikenal dengan istilah tindak pidana terhadap agama, yang digunakan untuk menjelaskan tentang tindak pidana yang berhubungan dengan keyakinan.

2. Ketentuan pasal 157 KUHP Ketentuan Pasal 157 KUHP di atas, dikenal dengan istilah kejahatan hate speech yaitu tindakan berupa lisan maupun tulisan yang 
dilakukan oleh individu atau kelompok dalam bentuk provokasi atau hasutan kepada individu atau kelompok yang lain dalam berbagai aspek seperti ras, agama, warna kulit, gender, cacat, orientasi seksual, kewarganegaraan dan lain sebagainya. Di negara yang multikultur dan multi agama tentu akan sangat rentan dengan isu penghinaan. Dilihat dari sifat agama, keyakinan seseorang terhadap satu hal dapat berbeda dengan keyakinan orang lain, bahkan menyalahkan keyakinan orang lain, dan perbedaan ini dapat dianggap sebagai penghinaan terhadap agama lain. ${ }^{12}$ Kembali pada strategi dan kebijakan Polri, untuk meningkatkan keamanan dan ketertiban dalam rangka penegakkan protokol kesehatan, Polri melakukan optimalisasi peran Bhayangkara Pembina Keamanan dan Ketertiban Masyarakat (Bhabinkamtibnas) dengan melakukan komunikasi secara langsung. Tentunya hal itu dilakukan dengan bekerjasama dengan RT/RW, Kepala Desa, Para Tokoh masyarakat, maupun orang-orang yang memiliki pengaruh di lingkungan tersebut. Segala upaya terus dilakukan mengingat pandemi membuat pertummbuhan ekonomi melambat yang berujung pada PHK missal, penghasilan menurun, dan sulitnya menjalankan usaha. Hal ini memicu tindakan kriminal, seperti pencurian, penjarahan, pembunuhan, dan tindakan kriminalitas dengan motif ekonomi lainnya. ${ }^{13}$

Fenomena penolakan jenazah dan pengambilan jenazah secara paksa menjadi indikasi yang menunjukan minimnya pengetahuan dan rendahnya kedisiplinan masyarakat terkait wabah Covid-19. Kembali Polri berperan aktif melakukan upaya persuasif yang tidak sekedar melakukan imbauan kepada masyarakat namun juga membangun komunikasi yang dapat diterima di kalangan masyarakat. Penyebaran virus yang masif ditekan dengan melakukan pemetaan oleh Polri pada wilayah yang rawan. Jajaran Polri juga membantu pemerintah daerah (pemda), seperti menyemprot tempat publik dengan cairan disinfektan, ikut serta mengukur suhu tubuh bersama dengan institusi terkait lainnya, mengatur lalu lintas, dan menerapkan larangan mudik sebagaimana disampaikan Presiden Joko Widodo yang meminta Polri dan TNI untuk memastikan kebijakan larangan mudik berjalan efektif. Tentu saja semua itu butuh kepiawaian improvisasi satker (satuan kerja) di lapangan. Dibutuhkan kemampuan anggota Polri untuk turut mengatasi masalah yang timbul dari ketidakpatuhan masyarakat. Pemahaman komunikasi antarbudaya masyarakat penting sekali agar tidak timbul kegaduhan. Polri juga terus

12 Nella Sumika Putri, Widati Wulandari dan Raden Ayumas Zisni, Kajian Tindak Pidana Terhadap Agama Di Indonesia Dibandingkan Dengan Pengaturannya Menurut Hukum Internasional Dan Di NegaraNegara Lain, DIPA FH Unpad, 2015, hlm, 9

13 Wiku Adisasmita (Ketua Tim Pakar Gugus Tugas Percepatan Penanganan Covid-19), wawancara oleh tim Media Indonesia, diakses dari: https://mediaindonesia.com/opini/324442/tantanganpolri-dalam-tatanan-kenormalan-baru , Pada 21 Februari 2021, pukul 13.01 Wib 
melakukan usaha yang inovatif dengan mengembangkan SDM anggotanya agar memiliki pengetahuan luas, baik secara akademis maupun praktik lapangan. Polisi dituntut harus sigap dan tanggap menghadapi perkembangan ancaman baru, seperti terorisme yang memiliki perkembangan metode dalam menggerakkan aksi mereka.

Tidak hanya menjaga dan mengayomi, Polri juga tidak lupa melakukan sumbangsih untuk membantu masyarakat. sejak pandemi mulai menjangkiti tanah air, Kapolri Jenderal Idham Azis sudah menginstruksikan kepada 500 Polres agar menyiapkan 10 ton beras dan bahan pokok lainnya untuk membantu warga terdampak pandemi. ${ }^{14}$ Sasaran bansos Polri disalurkan kepada fakir miskin, panti asuhan, panti sosial, masyarakat rentan, dan para pengemudi angkutan umum dan pengojek Ojol. Khusus bagi para sopir mereka selain mendapat bansos, Polri juga memberikan edukasi tentang protokol kesehatan dan protokol pencegahan covid-19 sebagai bekal mereka menjalani pekerjaan sebagai sopir. ${ }^{15}$ Polri dituntut bekerja keras dalam penegakkan hukum dan perlindungan masyarakat di masa pandemi. Di satu sisi tingkat rasio jumlah personel Polri dengan jumlah penduduk Indonesia memang masih belum ideal. Oleh karenanya daya dukung personel Polri juga perlu diperhatikan. Selain itu jumlah personel Polri yang terindikasi virus Covid-19 juga harus diperhatikan, ini penting untuk mengukur daya dukung personel Polri. Kesiapan sumber daya personel Polri dan kedisiplinan anggota Polri sendiri dalam menerapkan protokol kesehatan harus benar-benar diperhatikan.

\section{KESIMPULAN}

Dari pembahasan mengenai criminal policy dan peran serta Polri seta fungsi dan tugas Polri khususnya dalam pandemi virus Covid-19 maka dapa disimpulkan bahwa Polri sebagai instansi yang berperan dalam melindungi keamanan dan ketertiban dalam Negara serta sebagai penegak hukum telah menunjukan bahwa Polri berkomitmen untuk siap dalam keadaan apapun. Pandemi virus Covid-19 memang memberikan tugas berat di luar perkiraan. Namun Polri tetap sigap dan mampu bekerja sama dengan TNI juga khususnya tenaga medis dalam rangka menjaga protokol kesehatan, menertibkan dan mengawal jalannya Pembatasan Sosial Berskala Besar (PSBB). Polri memastikan masyarakat patuh terhadap aturan yang diberlakukan oleh pemerintah dalam rangka memutus rantai penyebaran virus Covid-19.

14 Diakses dari https://tribratanews.polri.go.id/read/1748/36/multi-peran-dijalani-polri-dimasa-pandemi-1598350137, pada 21 Februari 2021, Pukul 16.01 Wib

${ }^{15}$ Ibid 
Strategi dan kebijakan yang dibuat oleh Polri melalui Surat Telegram Kapolri adalah salah satu langkah untuk menepis pelanggaran dan mempertahankan keamanan dari tindak kejahatan baru maupun tindak kejahatan lain yang meningkat jumlahnya. Instruksi dari Kapolri memberikan pedoman bagi para anggotanya dalam melakukan tindakan dan keputusan baik dalam menangani pelanggaran terkait protokol kesehatan Covid-19 maupun terhadap tindak pidana yang muncul akibat dari pandemi. Hal ini tentunya tidak lepas dari peran serta masyarakat dan instansi yang lain yang secara bersama-sama bangkit untuk melepas Indonesia dari pandemi Virus Covid-19

\section{SARAN}

Polri diharapkan dapat berperan lebih dalam tatanan normal baru nantinya. Walaupun di masa pandemi, Polri sudah bergerak cepat dengan membentuk Satgas Covid-19. Dalam pedoman penegakan hukum yang disusun oleh Interpol dengan tajuk Covid-19 Pandemic, Polri diharapkan tidak sebatas penegakan hukum, namun juga berperan dalam upaya penanggulangan Covid-19. Peran itu diantaranya melakukan contact tracing pasien dan melacak pelebaran virus Covid-19, pengamanan infrastruktur penting (RS dan Apotek) serta pusat keramaian (Mall, pasar, bandara, stasiun) serta edukasi masyarakat.

Polri harus selalu menerapkan asas salus populi suprema lex esto (keselamatan rakyat adalah hukum tertinggi sebagai pedoman utama Polri dalam menjalankan tugasnya yang mana hal ini dapat terwujud apabila Polri dapat menjalankan tugas dan perannya secara optimal di masa pandemi.

\section{DAFTAR PUSTAKA}

Farouk Muhammad, Menuju Reformasi Polri, cet. Pertama April ,PTIK Press bekerjasama dengan, CV Restu Agung, Jakarta, 2013.

https://amp.kompas.com/nasional/read2021/02/02/12371171/ini-6-perintah-terbarukapolri-soal-penanganan-covid-19 , pada tanggal 18 Februari 2021, pukul 13.45

https://news.detik.com/berita-jawa-tengah/d-4939462/corona-mewabah-gubernurganjar-liburkan-sekolah-se-jateng pada tanggal 20 Februari 2021, Pukul 14.21 Wib

https://tribratanews.polri.go.id/read/1748/36/multi-peran-dijalani-polri-di-masapandemi-1598350137, pada 21 Februari 2021, Pukul 16.01 Wib

Kuntjoro Purbopranoto, Beberapa Catatan Hukum Tata Pemerintahan Dan Peradilan Administrasi Negara, Bandung, Alumni, 1981. 
Nella Sumika Putri, Widati Wulandari dan Raden Ayumas Zisni, Kajian Tindak Pidana Terhadap Agama Di Indonesia Dibandingkan Dengan Pengaturannya Menurut Hukum Internasional Dan Di Negara-Negara Lain, DIPA FH Unpad, 2015.

Pemidanaan dalam Pencegahan Covid-19 Upaya Terakhir https://nasional.kompas.com/read/2020/04/07/06291501/polri-pemidanaandalam-pencegahancovid-19-upaya-terakhir diakses ulang pada tanggal 18 Februari 2021, Pukul 12:30 Wib

Sumber: Update Corona Indonesia: Bertambah 1.331 \& Jatim Tertinggi, https://tirto.id/fJyL , diakses ulang pada tanggal 17 Februari 2021, pukul 21.33 Wib

Teguh Sudarsono, Bianglala, Seganteng Wacana dan Aktualisasi Kelangsungan Reformasi Polri yang Berkelanjutan, Mullia Angkasa, Jakarta, Cetakan Kedua 2015.

Tribunbanyumas.com dengan judul Polda Jateng: Hoax soal Corona didominasi pesan berantai dari WhatsApp, diakses pada tanggal 20 Februari, Pukul 15.20 Wib

Undang-Undang Dasar Negara Republik Indonesia Tahun 1945

Warsito Hadi Utomo, Hukum Kepolisian di Indonesia, (Jakarta : Presdtasi Pustaka, 2005)

Wiku Adisasmita (Ketua Tim Pakar Gugus Tugas Percepatan Penanganan Covid-19), wawancara oleh tim Media Indonesia, diakses dari: https://mediaindonesia.com/opini/324442/tantangan-polri-dalam-tatanankenormalan-baru, Pada 21 Februari 2021, pukul 13.01 Wib 